\title{
SUBSTITUSI RUMPUT LAPANG DENGAN PELEPAH DAUN KELAPA SAWIT FERMENTASI MENGGUNAKAN MIKROORGANISME LOKAL TERHADAP KECERNAAN NUTRIEN DAN TOTAL DIGESTIBLE NUTRIENT PADA SAPI JANTAN PERANAKAN
}

\author{
Native Grass Substitution with Fermented Oil Palm Fronds using Local Microorganisms Against \\ Digestibility of Nutrients and Total Digestible Nutrient in Crossbreed Bulls \\ Ari Ashari Harahap ${ }^{1 *}$, Nevy Diana Hanafi², Ma'ruf Tafsin², Sayed Umar ${ }^{2}$ \\ ${ }^{I}$ Post Graduate Program Magister of Animal Husbandry, Faculty of Agriculture, \\ University of North Sumatera \\ ${ }^{2}$ Department of Animal Husbandry, Faculty of Agriculture, University of North Sumatera \\ Jl. Dr. A. Sofian No, 3 Padang Bulan, Medan 20155 \\ *E-mail: ariashariharahap@gmail.com
}

Submitted : January 7, $2020 \quad$ Accepted : June 2, 2020

\begin{abstract}
ABSTRAK
Penelitian ini bertujuan untuk mengevaluasi subtitusi rumput lapang dengan pelepah daun kelapa sawit fermentasi menggunakan mikro organisme lokal (MOL) terhadap kecernaan nutrien dan total digestible nutrient (TDN) pada sapi jantan peranakan. Rancangan percobaan yang digunakan adalah rancangan acak kelompok terdiri dari 4 perlakuan dan 3 kelompok. Materi yang digunakan sebanyak 12 ekor sapi jantan peranakan berumur (12-18 bulan) dengan rata-rata bobot badan masing-masing $141 \mathrm{~kg}-$ $269 \mathrm{~kg}$. Parameter yang diamati adalah kecernaan nutrien dan TDN. Penggunaan pelepah sawit fermentasi dalam berbagai level berpengaruh sangat nyata $(\mathrm{P}<0,01)$ terhadap nilai kecernaan nutrien dan TDN. Hasil penelitian menunjukan bahwa perlakuan terbaik terdapat pada P3 yaitu konsentrat $+45 \%$ pelepah daun kelapa sawit fermentasi, mampu menggantikan rumput lapang sebagai bahan pakan. Kesimpulan dari penelitian ini adalah pemberian pakan pelepah sawit fermentasi MOL dapat menjadi bahan pakan alternatif pengganti rumput lapang dalam pemeliharaan sapi jantan peranakan.
\end{abstract}

Kata kunci : Fermentasi, Kecernaan nutrien, Pelepah Daun Kelapa Sawit, Rumput Lapang, Total digestible nutrient

\section{ABSTRACT}

This research aimed to analyze the native grass substitution of fermented oil palm fronds using local microorganisms (MOL) to digestibility of nutrients and total digestible nutrient (TDN) in crossbreed bulls. The experimental design was randomized complete block design consisting of 4 treatments and 3 groups. Experimental animals used 12 breeds of 12-18 months old crossbreed bulls with an average bodyweight $141-269 \mathrm{~kg}$. The observed parameters were nutrient digestibility and TDN. The use of fermented oil palm fronds in various levels had very significant effect $(P<0.01)$ on the nutrient digestibility value and TDN. The results showed that the best treatment was in $P 3$ which had $45 \%$ fermented oil palm frond was able to substituted native grass as feed material. The conclusion of this research was the feeding of fermented oil palm fronds could be used as an alternative feed material for replacement of native grass in maintenance of crossbreed bulls.

Keywords: Digestibility of Nutrients, Fermentation, Native Grass, Oil Palm Leaves, Total digestible nutrient 


\section{PENDAHULUAN}

Pelepah daun kelapa sawit merupakan limbah perkebunan kelapa sawit yang akan menjadi sampah pasca panen. Pada saat panen tandan buah segar, satu hingga dua helai pelepah kelapa sawit dipotong dengan tujuan memperlancar penyerbukan dan mempermudah panen berikutnya. Kelapa sawit yang telah berproduksi dapat menghasilkan 40 - 50 pelepah/ pohon per tahun. Satu hektar perkebunan kelapa sawit diperkirakan dapat menghasilkan 6.400 7.500 pelepah per tahun (Simanihuruk et al., 2007). Angka ini menunjukkan potensi besar dari pelepah kelapa sawit sebagai pakan ternak, namun pemanfaatannya terkendala dengan rendahnya tingkat kecernaan karena kadar Neutral Detergent Fiber (NDF) dan lignin yang tinggi (Imsya, 2009).

Teknologi fermentasi dapat dilakukan dengan cara melakukan fermentasi pada pelepah kelapa sawit menggunakan multi mikroba lokal (MOL) dan isolat rumen kerbau (Hanafi et al., 2016). Multi mikroba lokal yang digunakan antara lain Aspergillus niger dan Saccharomyces cerevisiae. Mikroorganisme lokal Saccharomyces cerevisiae dan isolat rumen kerbau merupakan salah satu fermentor yang mempunyai kemampuan untuk memecah molekul kompleks menjadi lebih sederhana misalnya pada serat kasar. Penelitian telah dilakukan oleh Tafsin et al. (2018) dengan menggunakan mikroorganisme lokal yang berisi Aspergillus niger, Saccharomyces cerevisiae dan isolat rumen kerbau mampu meningkatkan Koefisien Cerna Bahan Organik (KCBO) sebesar 73,88\%. Mulianda et al. (2018) menyatakan bahwa fermentasi pelepah sawit dengan penggunaan dosis mikroorganisme lokal $0,6 \%$ dapat meningkatkan kecernaan bahan oragnik pada pelepah kelapa sawit sebesar $65,78 \%$ lebih tinggi dibandingkan penggunaan dosis mikroorganisme lokal $0 \%$ memiliki kecernaan bahan oragnik $33,03 \%$.

Penelitian ini bertujuan untuk mengevaluasi subtitusi rumput lapang dengan pelepah daun kelapa sawit fermentasi menggunakan mikro organisme lokal (MOL) terhadap kecernaan nutrien dan total digestible nutrient (TDN) pada sapi jantan peranakan.

\section{MATERI DAN METODE}

Penelitan dilaksanakan di Peternakan Sapi Marihat Perkasa, Huta I Sembat, Marihat Baris, Kabupaten Simalungun, Provinsi Sumatera Utara.

\section{Materi}

Materi penelitian adalah 12 ekor sapi jantan peranakan (umur 12-18 bulan) dengan berat badan 141-269 kg. Bahan pakan yang digunakan yaitu pelepah daun kelapa sawit, rumput lapang, molases, urea, bungkil inti sawit, dedak padi, lumpur sawit, bungkil kedelai, bungkil kelapa, mineral premix dan $\mathrm{CaCO}_{3}$. Mikroba lokal yang digunakan terdiri dari Aspergillus niger, saccharomyces cerevisiae dan isolat bakteri rumen kerbau. Jumlah pemberian pakan disesuaikan dengan kebutuhan pakan menurut patokan yang diberikan oleh NRC sapi potong (Tabel 1).

\section{Metode}

Penelitian ini bersifat eksperimental menggunakan Rancangan Acak Kelompok (RAK) dengan 4 perlakuan dan 3 ulangan sehingga menjadi 12 petak percobaan. Perlakuan yang diberikan sebagai berikut.

P0 : Konsentrat $+0 \%$ Pelepah daun kelapa sawit fermentasi $+45 \%$ Rumput lapang

P1 : Konsentrat $+15 \%$ Pelepah daun kelapa sawit fermentasi $+30 \%$ Rumput lapang

P2: Konsentrat $+30 \%$ Pelepah daun kelapa sawit fermentasi $+15 \%$ Rumput lapang

P3 : Konsentrat $+45 \%$ Pelepah daun kelapa sawit fermentasi + 0\% Rumput lapang

\section{Parameter}

\section{1) Kecernaan Nutrien}

Pengukuran kecernaan nutrien yaitu, kecernaan bahan kering, kecernaan bahan organik, protein kasar dan kecernaan serat kasar, kecernaan lemak kasar dan BETN. Perhitungan kecernaan nutrien dapat diukur menggunakan rumus sebagai berikut:

Kecernaan Nutrien $=$

Nutrien konsumsi - Nutrien feses x 100\%

Nutrien konsumsi

Konsumsi dan pengeluaran feses (nutrien) diperoleh dalam jangka waktu pengukuran selama periode koleksi yaitu selama satu minggu.

\section{2) Total Digestible Nutrient}

TDN dapat diukur dengan menghitung berdasarkan rumus sebagai berikut (Hartadi et al, 1990) :

$\mathrm{TDN}=\%$ PK dapat dicerna $(\mathrm{dd})+\% \mathrm{SK} d \mathrm{~d}+\%$ BETN dd $+2,25 \times \%$ LK dd 


\section{Analisis Data}

Data penelitian dianalis menggunakan analisis sidik ragam (analysis of variance/ANOVA), jika terdapat perbedaan rataan perlakuan dilakukan uji Duncan's Multiple Range Test (DMRT)

\section{HASIL DAN PEMBAHASAN}

\section{Kecernaan Nutrien}

\section{a. Kecernaan bahan kering}

Tabel 2 menunjukkan bahwa terdapat perbedaan signifikan $(\mathrm{P}<0,01)$ terhadap rataan kecernaan bahan kering. Rataan kecernaan bahan kering tertinggi pada perlakuan P3 (level subtitusi rumput $45 \%$ ) yaitu $62,22 \%$ dan rataan kecernaan bahan kering terendah $\mathrm{P} 0$ (level subtitusi rumput $0 \%$ ) yaitu $50,05 \%$, semakin tinggi level subtitusi rumput dengan pelepah daun kelapa sawit fermentasi pada ransum semakin meningkatkan nilai kecernaan bahan kering ransum pada ternak sapi.

Hasil rataan kecernaan bahan kering yang diperoleh dari penelitian ini yaitu $62,22 \%$, nilai kecernaan bahan kering pada penelitian ini memiliki rataan lebih rendah dibandingkan dengan penelitian Mulianda et al. (2018) yaitu $62,55 \%$ dan nilai kecernaan bahan kering pada penelitian ini memiliki rataan sedikit lebih tinggi dibandingkan dengan hasil penelitian Tafsin et al. (2018) yang menggunakan mikroorganisme lokal yang berisi Aspergillus niger, Saccharomyces cerevisiae, dan isolat rumen kerbau mampu meningkatkan kecernaan bahan kering yaitu $58,56 \%$.

Tabel 1. Bahan pakan perlakuan (Treatment feed ingredients)

\begin{tabular}{|c|c|c|c|c|}
\hline \multirow{2}{*}{$\begin{array}{c}\text { Bahan Pakan } \\
\text { (Feed Ingredients) }\end{array}$} & \multicolumn{4}{|c|}{ Perlakuan (Treatment, \%) } \\
\hline & P0 & P1 & P2 & P3 \\
\hline Molases & 4 & 4 & 4 & 4 \\
\hline Urea & 1 & 1 & 1 & 1 \\
\hline BIS & 13 & 13 & 13 & 13 \\
\hline Rumput Lapang & 45 & 30 & 15 & 0 \\
\hline Pelepah daun Kelapa Sawit & 0 & 15 & 30 & 45 \\
\hline Dedak Padi & 5 & 5 & 5 & 5 \\
\hline Lumpur Sawit & 16 & 16 & 16 & 16 \\
\hline Bungkil kedelai & 6 & 6 & 6 & 6 \\
\hline Bungkil Kelapa & 8 & 8 & 8 & 8 \\
\hline Ultra Mineral & 1 & 1 & 1 & 1 \\
\hline $\mathrm{CaCo} 3$ & 1 & 1 & 1 & 1 \\
\hline Total & 100 & 100 & 100 & 100 \\
\hline \multicolumn{5}{|l|}{$\begin{array}{l}\text { Kandungan Nutrisi* } \\
\text { (Nutritional Content } * \text { ) }\end{array}$} \\
\hline PK & 14,6 & 14,29 & 13,97 & 13,66 \\
\hline TDN & 60,79 & 61,16 & 61,53 & 61,9 \\
\hline $\mathrm{Ca}$ & 1,3 & 1,49 & 1,59 & 1,7 \\
\hline $\mathrm{P}$ & 0,71 & 0,71 & 0,71 & 0,71 \\
\hline
\end{tabular}

Keterangan : *Berdasarkan perhitungan (*Based on calculations)

Tabel 2. Hasil penelitian kecernaan nutrien dan total digestible nutrient. (Results of research to digestibility of nutrients and total digestible nutrient).

\begin{tabular}{cccccccc}
\hline \multirow{2}{*}{$\begin{array}{l}\text { Perlakuan } \\
\text { (Treatment) }\end{array}$} & \multicolumn{7}{c}{$\begin{array}{c}\text { Kecernaan } \\
\text { (Digestiblity, \%) }\end{array}$} \\
\cline { 2 - 7 } & BK & BO & PK & SK & LK & BETN & TDN \\
\hline P0 & $50,05^{\mathrm{b}}$ & $46,84^{\mathrm{b}}$ & $69,55^{\mathrm{ab}}$ & $54,67^{\mathrm{a}}$ & $88,30^{\mathrm{c}}$ & $41,04^{\mathrm{b}}$ & $50,58^{\mathrm{b}}$ \\
P1 & $53,06^{\mathrm{b}}$ & $52,52^{\mathrm{ab}}$ & $64,20^{\mathrm{b}}$ & $55,06^{\mathrm{a}}$ & $90,79^{\mathrm{b}}$ & $51,76^{\mathrm{ab}}$ & $40,79^{\mathrm{ab}}$ \\
P2 & $55,74^{\mathrm{b}}$ & $50,27^{\mathrm{ab}}$ & $69,54^{\mathrm{ab}}$ & $33,32^{\mathrm{b}}$ & $91,88^{\mathrm{b}}$ & $66,41^{\mathrm{a}}$ & $57,94^{\mathrm{ab}}$ \\
P3 & $62,22^{\mathrm{a}}$ & $60,91^{\mathrm{a}}$ & $76,72^{\mathrm{a}}$ & $48,74^{\mathrm{a}}$ & $96,00^{\mathrm{a}}$ & $64,95^{\mathrm{a}}$ & $62,44^{\mathrm{a}}$ \\
\hline
\end{tabular}

Keterangan : Huruf superskrip berbeda pada kolom yang sama menunjukkan perbedaan signifikan $(\mathrm{P}<0,01) . \mathrm{BK}=$ Bahan Kering, $\mathrm{BO}=$ Bahan Organik, $\mathrm{PK}=$ Protein Kasar, $\mathrm{SK}=$ Serat Kasar, LK = Lemak Kasar, BETN = Bahan Ekstrak Tanpa Nitrogen, TDN $=$ Total Digestible Nutrient. 
Perbedaan ini disebabkan karena metode penelitian dan komposisi bahan pakan dan ransum ternak yang digunakan berbeda yaitu pada penelitian ini menggunakan metode in vivo dan menggunakan pakan komplit sedangkan pada penelitian Mulianda et al. (2018) dan Tafsin et al., (2018) menggunakan metode in vitro dan hanya menggunakan pelepah daun kelapa sawit fermentasi.

\section{b. Kecernaan bahan organik}

Tabel 2 menunjukkan bahwa terdapat perbedaan signifikan $(\mathrm{P}<0,01)$ terhadap rataan kecernaan bahan organik. Rataan kecernaan bahan organik tertinggi pada perlakuan P3 (level subtitusi rumput $45 \%$ ) yaitu $60,91 \%$ dan rataan kecernaan bahan organik terendah pada perlakuan P0 (level subtitusi rumput $0 \%$ ) yaitu 46,84\%. Hal ini menunjukkan bahwa substitusi pelepah daun kelapa sawit yang difermentasi menggunakan Aspergillus niger, Saccharomyces cerevisiae, dan isolat bakteri rumen kerbau dapat meningkatkan kecernaan bahan organik yaitu 60,91\%. Mulianda et al. (2018) menunjukkan hasil rataan kecernaan bahan organik pada fermentasi pelepah sawit dengan penggunaan dosis mikroorganisme lokal $0,6 \%$ yaitu $62,70 \%$. Nilai kecernaan bahan organik pada penelitian ini memiliki rataan lebih rendah dibandingkan dengan penelitian Mulianda et al. (2018) dan Tafsin et al. (2018) dengan menggunakan mikroorganisme lokal yang berisi Aspergillus niger, Saccharomyces cerevisiae, dan isolat rumen kerbau mampu meningkatkan kecernaan bahan organik sebesar 73,88\% .

\section{c. Kecernaan protein kasar}

Tabel 2 menunjukkan bahwa terdapat perbedaan signifikan $(\mathrm{P}<0,01)$ terhadap rataan kecernaan protein kasar. Rataan kecernaan protein kasar tertinggi terdapat pada perlakuan P3 (level subtitusi rumput $45 \%$ ) yaitu $76,72 \%$ dan kecernaan protein kasar terendah terdapat pada perlakuan P1 (level subtitusi rumput 15\%) yaitu 64,20\%. Hasil ini lebih tinggi dibandingkan dengan hasil penelitian Delfia et al. (2014) bahwa kecernaan protein kasar sapi Bali yang diberi pakan dengan berbagai level pelepah sawit yaitu $68,18 \%$. Lignase yang diproduksi oleh Aspergillus niger dapat memecah ikatan lignin polisakarida menjadi bagian yang lebih sederhana. Saccharomyces cerevisiae juga sebagai salah satu galur yang paling umum digunakan untuk fermentasi, karena bersifat fermentatif kuat dan anaerob fakultatif (mampu hidup dengan atau tanpa oksigen), memiliki sifat yang stabil dan seragam, mampu tumbuh dengan cepat saat proses fermentasi sehingga proses fermentasi berlangsung dengan cepat pula (Winarno, 1992).

Mikroba rumen dapat meningkatkan nilai gizi bahan makanan karena adanya protein mikroba sehingga akan meningkatkan daya cerna, selain itu rumen diakui sebagai sumber enzim pendegradasi polisakarida. Polisakarida di hidrolisis di rumen disebabkan pengaruh sinergis dan interaksi dari kompleks mikroorganisme, terutama selulase dan xilanase. Mikroorganisme didalam rumen akan memfermentasi karbohidrat yang spesifik dibutuhkan enzim yang digunakan untuk mendegradasi substrat sebagai sumber energi (Jhonson, 1996).

\section{d. Kecernaan serat kasar}

Tabel 2 menunjukkan bahwa terdapat perbedaan yang signifikan $(\mathrm{P}<0,01)$ terhadap rataan kecernaan serat kasar. Rataan kecernaan serat kasar tertinggi terdapat pada perlakuan P1 (level subtitusi rumput $15 \%$ ) yaitu $55,06 \%$ dan kecernaan serat kasar terendah terdapat pada perlakuan P2 (level subtitusi rumput 30\%) yaitu $33,32 \%$. Hasil ini lebih rendah dibandingkan dengan hasil penelitian Febrina (2012) yang melaporkan kecernaan serat kasar ransum sapi Peranakan Ongole berbasis limbah perkebunan kelapa sawit yang diamoniasi urea yaitu $89,45 \%$. Substitusi pelepah daun kelapa sawit yang difermentasi menggunakan Aspergillus niger, Saccharomyces cerevisiae, dan isolat bakteri rumen kerbau menurunkan kecernaan serat kasar yaitu 33,32\%. Menurut Despal (2000) kandungan serat kasar memiliki hubungan yang negatif dengan kecernaan, semakin rendah serat kasar maka semakin tinggi kecernaan ransum. Mc Donald et al. (2002) menyatakan bahwa serat kasar yang terkandung pada pakan tiap perlakuan sangat penting pengaruhnya terhadap daya cerna serat kasar ternak terhadap pakan tersebut.

\section{e. Kecernaan lemak kasar}

Tabel 2 menunjukkan bahwa terdapat perbedaan yang signifikan $(\mathrm{P}<0,01)$ terhadap rataan kecernaan lemak kasar. Rataan kecernaan lemak kasar yang paling tinggi terdapat pada perlakuan P2 (level subtitusi rumput 30\%) yaitu 91,88\% dan rataan kecernaan lemak kasar terendah pada perlakuan P0 (level subtitusi rumput $0 \%$ ) yaitu $88,30 \%$. Nilai kecernaan lemak kasar pada penelitian ini memiliki rataan yaitu $90,00 \%$, sedikit lebih tinggi dibandingkan dengan hasil penelitian Febrina (2012) yang melaporkan kecernaan serat lemak kasar ransum sapi peranakan ongole berbasis limbah perkebunan kelapa sawit yang diamoniasi urea yaitu $81,21 \%$. Kandungan lemak kasar yang tinggi pada bahan 
pakan ternak ruminansia dapat mengganggu proses fermentasi bahan pakan dalam rumen ternak.

\section{f. Kecernaan bahan ekstrak tanpa nitrogen} Tabel 2 menunjukkan bahwa terdapat perbedaan yang signifikan $(\mathrm{P}<0,01)$ terhadap rataan kecernaan bahan ekstrak tanpa nitrogen (BETN). Rataan kecernaan BETN tertinggi terdapat pada perlakuan $\mathrm{P} 2$ (level subtitusi rumput $30 \%$ ) yaitu $66,41 \%$ dan rataan kecernaan bahan ekstrak tanpa nitrogen terendah terdapat pada perlakuan P0 (level subtitusi rumput $0 \%$ ) yaitu $41,04 \%$. Nilai kecernaan BETN pada penelitian ini memiliki rataan yaitu $66,41 \%$. Hal tersebut menunjukkan bahwa substitusi rumput lapang dengan pelepah daun kelapa sawit fermentasi Aspergillus niger, Saccharomyces cerevisiae, dan isolat bakteri rumen kerbau meningkatkan BETN. Menurut Kamal (1998) dan Sutardi (2006) bahwa BETN dipengaruhi oleh kandungan nutrien lainnya yaitu protein kasar, air, abu, serat kasar dan lemak kasar.

\section{Total Digestible Nutrient}

Nilai total digestible nutrient (TDN) diperoleh dari hasil penjumlahan kecernaan protein kasar, serat kasar, lemak kasar, dan bahan ekstrak tanpa nitrogen. Berdasarkan Tabel 2 menunjukkan bahwa terdapat perbedaan yang signifikan $(\mathrm{P}<0,01)$ terhadap rataan TDN. Rataan TDN tertinggi terdapat pada perlakuan P3 (level subtitusi rumput $30 \%$ ) yaitu 62,44 dan rataan TDN terendah terdapat pada perlakuan P1 (level subtitusi rumput $15 \%$ ) yaitu 40,79. Nilai energi tersebut tergantung pada kecernaan bahan organik pakan, nutrien (protein kasar, serat kasar, lemak kasar dan bahan ekstrak tanpa nitrogen) (Hermanto, 2001).

\section{SIMPULAN DAN SARAN}

\section{Simpulan}

Pemberian pakan pelepah sawit fermentasi mikro organisme lokal (MOL) dapat menjadi bahan pakan alternatif pengganti rumput lapang dalam pemeliharaan sapi jantan peranakan dengan level terbaik subtitusi rumput $45 \%$.

\section{Saran}

Masyarakat dan peternak dapat menggunakan $45 \%$ pelepah daun kelapa sawit fermentasi mikroorganisme lokal Aspergillus niger, Saccharomyces cerevisiae, dan isolat bakteri rumen kerbau sebagai bahan penyusun ransum pakan ternak.

\section{UCAPAN TERIMAKSIH}

Ucapan terimakasih penulis sampaikan juga kepada Direktorat Riset dan Pengabdian Masyarakat (DRPM) Kementerian Riset, Teknologi dan Pendidikan Tinggi Tahun 2018 yang telah mendanai penelitian ini serta segenap dosen, civitas akademika dan teman-teman mahasiswa pscasarjana.

\section{DAFTAR PUSTAKA}

Delfia, D. N, A. Purnomoadi, dan L. N. Kustiawan. 2014. Penampilan produksi Sapi Bali yang diberi pakan dengan berbagai level pelepah sawit. J. Ilmiah Peternakan Agromedia 32(2): 54-61.

Despal. 2000. Kemampuan komposisi kimia dan kecernaan in vitro dalam mengestimasi kecernaan in vivo. Med. Pet. 23(3): 84-88).

Febrina, D. 2012. Kecernaan ransum sapi Peranakan Ongole berbasis limbah perkebunan kelapa sawit yang diamoniasi urea. J. Peternakan 9(2): 68 - 74.

Hanafi, N. D., M Tafsin, dan W. Sujana. 2016. Penggunaan multi mikroba lokal dengan berbagai dosis dan lama inkubasi terhadap kecernaan bahan kering dan bahan organik pelepah kelapa sawit in vitro. $J$. Peternakan Integratif 4(2): 133-142.

Hermanto, A. 2001. Pakan Alternatif Sapi Potong. Dalam Kumpulan Makalah Lahirnya Kajian Teknologi Pakan Ternak Alternatif. Pakan Ternak Alternatif. Fakultas Peternakan Universitas Brawijaya. Dinas Peternakan Provinsi Jawa Timur. Surabaya.

Imsya, A. 2009. The change of lignin, NDF (Neutral Detergent Fiber), dan ADF (Acid Detergent Fiber) palm fronds with biodegumming process as fiber source feedstuff for ruminantia. JITV 14(4): 284288.

Jhonson, R.R. 1996. Technics and Prosedures for In-Vitro and In-Vitro Rumen Studies. New York.

Kamal, M. 1998. Nutrisi Ternak I. Rangkuman. Laboratorium Makanan Ternak Jurusan Nutrisi dan Makanan Ternak Fakultas Peternakan Universitas Gadjah Mada. Yogyakarta.

Mc Donald, P., R. Edwards, J. Greenhalgh, and C. Morgan. 2002. Animal Nutrition. $6^{\text {th }}$ Edition. Longman Scientific \& Technical, New York.

Mulianda, R., M. Tafsin, N.D. Hanafi, Yulinas. 2018. Utilizing local microorganisms with 
different dosages and duration of fermentation towards digestibility and rumen activity of oil palm frond in vitro. CSSPO 2018. https://doi.org/10.1051/e3sconf/20185200 036

Simanihuruk, K. J., L. P. Batubara, A. Tarigan, R. Hutasoit, T.M. Hutauruk, Supriyatna, M. Situmorang, Taryono. 2007. Pemanfaatan Pelepah Kelapa Sawit sebagai Pakan Basal Kambing Kacang Fase Pertumbuhan. Laporan Akhir Kegiatan Penelitian. Loka Penelitian Kambing Potong Sei Putih. Pengembangan Peternakan. Bogor.

Sutardi, T. 2006. Landasan Ilmu Nutrisi Jilid 1. Departemen Ilmu Makanan Ternak Fakultas Peternakan Institut Pertanian Bogor. Bogor

Tafsin, M., Y. Khairani, N.D. Hanafi, dan Yunilas. 2018. In vitro digestibility of oil palm frond treated by local mocroorganism (MOL). IOP Publishing. 10.1088 (1755-1315).

Winarno, F.G., S. Fardiaz, D. Fardiaz. 1992. Pengantar Teknologi Pangan. Gramedia. Jakarta 